\title{
Accelerating innovation adoption in the "Tagrinov" program in Bali Province
}

\author{
I Ketut Mahaputra*, Jemy Rinaldi, Nyoman Ngurah Arya, Tulus Fernando Silitonga, and Ni
} Ketut Sudarmini

Assessment Institute for Agricultural Technology Bali, Jl. By Pass Ngurah Rai Pasanggaran

Denpasar, Bali, Indonesia

\begin{abstract}
One of the natural resources that has the potential to improve the performance of rural farmers is the use of yards. Various efforts have been made by the Ministry of Agriculture, one of which is the Agricultural Innovation Gardens (Tagrinov), which has been a model for government offices. This research was conducted in Bengkel Village, Buleleng Regency, in October-December 2019. The number of respondents was set at 30 farmers implementing the program. The study aim is to identify the level of group adoption of disseminated technological innovations that are profit-oriented farmer groups. The basic research method is descriptive method, using survey technique. The classification of the level of farmer adoption of the technology is divided into 3 categories (high, medium and low) using intervals. The adoption rate analysis for the herd level used the formula $\mathrm{N}=\mathrm{SA} \times \mathrm{IA}$. Followed by analysis of farm income using the following approach: $\mathrm{Pd}=\mathrm{TR}-\mathrm{TC}$. The results showed the effectiveness of increasing farmers' knowledge by $64.68 \%$ (quite effective), farmers' attitudes towards the material increased by 3.86 (good category), group adoption rate by $88.11 \%$ (high adoption) and as a whole can provide additional income for farmer groups of Rp.752.556,-/month.
\end{abstract}

\section{Introduction}

One of the natural resources that have the potential to improve the performance of rural farmers are the use of yards. Business in the yard if managed intensively in accordance with the potential of the yard itself can meet household consumption needs and provide additional income for households. The yard has various functions that can produce additional food ingredients in the form of vegetables and fruits, poultry, fish, medicinal plants and other money-generating activities. This has been described by the Ministry of Agriculture through the KRPL (Sustainable Food House Area) program which has been implemented nationally.

Utilization of yards can be carried out through integrated yard intensification activities, by integrating three sub-sectors within the yard, namely agriculture, animal husbandry and fisheries, which are adjusted to the availability of resources, knowledge, and social

* Corresponding author: ﹎. mahaputra@yahoo.com 
behavior of the local community. Several studies related to the use of the yard show that plants and livestock in the yard contribute to family income [1]. The income obtained from the yard in Sambirejo Village, Ngawen District, GunungKidul Regency each month ranges from Rp. 335,000 - Rp. 2,246,428 [2]. However, with a better yard arrangement, it can provide income of up to Rp. 3,236,821 per month or Rp. 38,841,848 per year [3]. The results of this study prove that the yard can be used as an effective farming land to support the family food security program in urban and rural areas.

In its development in the area is expected the program managers to master the concepts and empowerment programs that have been implemented as well as the related pilot optimizing the utilization of the yard that has not been in utilized particularly in support of national food security. For this reason, the Indonesian Agency for Agricultural Research and Development since 2015 has developed this Agro-Innovation Park and Agrimart at every AIAT (Assessment Institute for Agricultural Technology) throughout Indonesia which basically has three functions, namely : 1) As an Agro-Innovation Park to develop various superior technologies of Balitbangtan (Indonesia Agency of Agricultural Research and Technology) on a compact and compact expanse. strategically around institution, as well as a source of stock of seeds/seeds supplied as a location for visits by potential technology users ; 2) as an Agribusiness Clinic, namely as a forum for the dissemination of agricultural innovations through services, consultation, training, internships and the provision of agricultural technology information materials; and 3) as an Agro Innovation Mart (AGRIMART) namely as a forum for the implementation of technology dissemination as a commercial activity in collaboration with the business world, (cooperatives, private sector, BUMN/BUMD and others).

It was further emphasized that in the future Agrimart and Agro Innovation Park will become an effective means of disseminating various location-specific technologies as well as developing agribusiness units that lead to improving the welfare of farmers/communities [4]. The Tagrimart program displays various strategic commodities that can be replicated by users in the form of an Agro Innovation Park equipped with an Agro Innovation Mart (Agrimart) as a form of commercialization of the application of innovation. Thus, onfarm agricultural innovation cannot be separated from off-farm. Innovation is a complete series from upstream to downstream, so that in the application of agricultural innovations must also pay attention to feasibility and marketing.

In an effort to accelerate the process of diffusion and adoption of technological innovations that have been produced, it is necessary to make a breakthrough by disseminating the results of research and assessment in various forms of dissemination activities in various locations, both in the form of technological components and in the form of technology packages. The development of independent dissemination, as an independent business entity (not a cost center) needs to be initiated at AIAT through optimizing the role of the Agro Innovation Park and initiating the development of the Agro Innovation Mart. For that on 2019, the Tagrimart demonstration plot was carried out in the district as one of the developments of the Tagrimart program which has been implemented in office areas, with an emphasis on commodities of economic value that can be a source of income for farmers. This study aims to see the level of group adoption of technological innovations that are profit-oriented to farmer groups.

\section{Research method}

The basic research method was a descriptive method. This study used a survey technique, is a research technique by taking a sample from a population by using a questionnaire as a data collection tool for a particular problem in a certain area. The research was conducted at the location of the Tagrimart demonstration plot in Bengkel Village, Busungbiu District, 
Buleleng Regency which was determined purposively. The activity was carried out in October-December 2019. The number of respondents was determined as many as 25 farmers. Methods used a survey questionnaire tools. Level of knowledge and attitude of farmers as individuals using a Pre-test and Post-test with tools questionnaire. The level of technology adoption in the group was measured by a scoring technique. How the classification level of adoption technology program Tagrimart divided into 3 categories (classes) that is high category, medium and low categories, and use the interval by the formula [5]:

$$
I=\frac{J}{K}
$$

Where:

$\mathrm{I}=$ Class interval; $\mathrm{J}=\mathrm{j}$ the distance between the maximum score and the minimum score; and $\mathrm{K}=$ $b$ number of classes used.

Furthermore, the classification of farmer adoption rates is classified according to the calculation results obtained, namely: (1) low adoption and (2) medium and (3) high adoption. This activity is based on 5 main components of technological innovation developed, namely: 1) seed preparation technology, 2) garden plant cultivation technology, 3) organic pesticide manufacturing technology, 4) purple eggplant product processing, and 5) vegetable product processing. Analysis of the adoption rate for the livestock group level uses the formula [6]:

$\mathrm{TA}=\mathrm{SA} \times \mathrm{IA}$,

where:

$\mathrm{SA}=\mathrm{n} / \mathrm{N} \times 100 \%$

$\mathrm{IA}=\mathrm{nx} \mathrm{NB/T}$

Information:

$\mathrm{TA}=$ Adoption rate $(\%)$

$\mathrm{SA}=$ Adoption Spread (\%)

$\mathrm{IA}=$ Intensity of adoption $(\%)$

$\mathrm{n}=$ number of adopters (people)

$\mathrm{N}$ = number of group members (people)

$\mathrm{T}=$ Total recommended technology components (units)

$\mathrm{NB}=$ Weighted value of adoption observations in the field (adoption unit)

The adoption level classification is set into 3 classes (based on expert judgment), namely:

$0-44.99 \%=$ low adoption rate classification

$45-64.99 \%=$ medium adoption rate classification

$65-100 \%=$ high adoption rate classification

Followed by a partial analysis of farm income using the income approach, namely the mathematical formula: $\mathrm{Pd}=\mathrm{TR}-\mathrm{TC}$

\section{Result and discussion}

\subsection{Evaluation of knowledge and attitudes towards technical guidance participants at other KRPL assistance locations in Buleleng Regency}

The technical guidance was carried out to groups of recipients of the Tagrinov program in Buleleng Regency. Technology guidance (Bimtek) related to processing of agricultural products such as making of candied jackfruit and floss held together with the Office of Food Security in Buleleng. It should be stated that the farmers implementing the Tagrinov program are mostly housewives. The use of narrow land and yard land is usually done by women in their spare time at home. This is in line with the thoughts of Fitri and Suryani [7] 
that agricultural activities in urban areas on limited land in Jakarta are the cultivation of vegetables, secondary crops and horticulture whose perpetrators are housewives and the elderly.

To determine the level of effectiveness of increasing knowledge and the effectiveness of technical guidance activities, pre-test and post-test assessments were carried out on respondents. The instrument used was a questionnaire containing 20 questions regarding knowledge and attitudes related to the material presented. The evaluation results can be explained as follows:

\subsubsection{Aspect of knowledge}

The results of the evaluation of the pre-test and post-test of respondents' knowledge level are presented in Table 1.

Table 1. Distribution of respondents' knowledge levels based on pre-test and post-test results

\begin{tabular}{|c|l|c|c|c|c|c|c|}
\hline \multirow{2}{*}{ No } & \multirow{2}{*}{ Category } & \multicolumn{3}{|c|}{$\begin{array}{c}\text { Average value } \\
\text { pre-test }\end{array}$} & \multicolumn{3}{c|}{$\begin{array}{c}\text { Average value } \\
\text { post test }\end{array}$} \\
\cline { 3 - 8 } & & Average & $\begin{array}{c}\text { N } \\
\text { (person) }\end{array}$ & $\mathbf{( \% )}$ & Average & $\begin{array}{c}\text { N } \\
\text { (person) }\end{array}$ & \multirow{2}{*}{ (\%) } \\
\hline 1 & Less & 2.03 & 18 & 72 & & & \\
\hline 2 & Enough & 2.51 & 7 & 28 & 3.55 & 6 & 24 \\
\hline 3 & Good & - & - & - & 4.13 & 19 & 76 \\
\hline \multicolumn{2}{|c|}{ Average } & 2.27 & & & 3.84 & & \\
\hline \multicolumn{2}{|c|}{ amount } & & 25 & 100 & & 25 & 100 \\
\hline
\end{tabular}

Source: Processed primary data, 2019.

Information:

Less $=1.0-2.3$

Enough $=2.4-3.7$

Good $=3.8-5.0$

According to Ginting [8] the criteria for the effectiveness of increasing knowledge and the effectiveness of extension programs are as follows: Effective $(66.66 \%)$, quite effective $(33.33-66.66 \%)$, and less effective $(<33.33 \%)$. Based on the results of the evaluation of the technical guidance activities carried out it was quite effective, where the results of the effectiveness value of increasing knowledge were $64.68 \%$ and the program effectiveness value obtained was $79.8 \%$ (effective).

Technology guidance activities are one of the methods used to carry out the dissemination of technological innovations. The technology presented is how to process starfruit into sweets and jackfruit into shreds. The material presented is an introduction to tools, materials, manufacturing techniques and product packaging resulting from the processing of these results. The effectiveness of this innovation dissemination activity is inseparable and highly dependent on the selection of materials, media, as well as methods and techniques that are in accordance with the circumstances and needs of the target. The method used in the technical guidance is a group approach combined with discussion techniques and demonstration methods so that farmers can see firsthand and work together on the theory presented.

\subsubsection{Attitude aspect}

The results of the pre-test and post-test evaluations of respondents' attitudes towards the material presented in the technical guidance activities are presented in Table 2. It can be explained that the attitude of the technical guidance participants to the material for 
processing agricultural products is in the poor category with an assessment score of 2.39. After the technical guidance activities were carried out and an assessment ( post $t$ test ) was carried out, the participant's attitude score increased to 3.86 in the good category. This is because at the time before being given the technical guidance material, the respondents did not understand and were not familiar with the ingredients and how to make the candied star fruit and shredded jackfruit. Participants were still hesitant and even tended not to accept the statements/questions posed in the pre-test questionnaire. After the implementation of technical guidance, farmers' understanding and insight were more open so that they received more benefits from the material, which can be seen from the increase in the average score from 2.39 in the poor category to 3.86 in the good category

Table 2. Results of the Evaluation of respondents' attitudes to the materials for technology guidance

\begin{tabular}{|c|l|c|c|c|c|c|c|}
\hline \multirow{2}{*}{ No } & \multirow{2}{*}{ Category } & \multicolumn{3}{|c|}{$\begin{array}{c}\text { Average value } \\
\text { pre-test }\end{array}$} & \multicolumn{3}{c|}{$\begin{array}{c}\text { Average value } \\
\text { post test }\end{array}$} \\
\cline { 3 - 8 } & & Average & $\begin{array}{c}\text { n } \\
\text { (person) }\end{array}$ & (\%) & Average & $\begin{array}{c}n \\
\text { (person) }\end{array}$ & (\%) \\
\hline 1 & Less & 2.19 & 17 & 75 & & & \\
\hline 2 & Enough & 2.58 & 8 & 25 & 3.68 & 4 & 16 \\
\hline 3 & Good & & & - & 4.05 & 21 & 84 \\
\hline \multicolumn{2}{|c|}{ Average } & 2.39 (less) & & & 3.86 (good) & & \\
\hline \multicolumn{2}{|c|}{ amount } & & 25 & 100 & & 25 & 100 \\
\hline
\end{tabular}

Source: Processed primary data

This shows that the innovation material delivered will be accepted by farmers more quickly if the material delivered is in accordance with the farmers' needs, the right delivery technique and the method used in delivering the material In choosing the technique and method of delivering technological innovation, it is very important to pay attention to the target conditions, including : age, level of education and motivation of the target. Besides that, good communication between facilitators and participants is very important to build on the implementation of technical guidance in the field, including communication of technological innovations in the era of increasingly sophisticated information technology development which is very important in today's era.

According to L. Darmawan, et al. [9], communication of innovation is a way of conveying the discovery of new ideas to the community so that there will be a social change for the better in the goal of food independence. Things like this will be easily accepted by today's farmers who are often called millennial farmers or cosmopolitanfarmers. Cosmopolitan farmers are farmers who are more open to accepting new innovations, because most of them get information and knowledgein agriculture from various sources such as training, from information media or from the experience of successful farmers [10]. So the more farmers are called cosmopolitan, the greater the desire of farmers towards modernity [11].The role of the government in the dissemination of agricultural technology through training is still very much needed by farmers in Bali. Likewise, research related to Small-Scale Agriculture in Improving Household Food in South Africa [12] said the government should organise workshops and trainings that are directed at empowering smallscale farmers and agricultural cooperatives with business skills as well as new technological farming methods

\subsection{Measurement of adoption rates in groups}

In disclosing the adoption rate by women farmer groups, calculations are used by considering the Adoption Distribution (SA) and Adoption Intensity (SA). There are 5 components of the technology introduced in the Tagrimart demonstration plot in the district, including: 1) seed preparation technology, 2) garden plant cultivation technology, 
3) organic pesticide manufacturing technology, 4) purple eggplant product processing, and 5) vegetable product processing. The calculation results are shown in Table 3.

Table 3. The level of adoption in farmer groups of the technology component that is disseminated

\begin{tabular}{|c|c|c|c|c|c|c|c|c|}
\hline No & Technology Type & $\mathbf{N}$ & $\begin{array}{l}\text { SA } \\
(\%)\end{array}$ & Rank & Weight & $\begin{array}{l}\text { Weight } \\
\text { Value }\end{array}$ & $\begin{array}{l}\text { HE } \\
(\%)\end{array}$ & $\begin{array}{l}\text { TA } \\
(\%)\end{array}$ \\
\hline \multirow[t]{4}{*}{1} & Seed preparation & & & & & & & \\
\hline & - Media setup & 27 & 90.00 & 1 & 10 & 14.71 & 33.09 & 29.78 \\
\hline & - Soaking seeds & 15 & 50.00 & 2 & 9 & 13.24 & 16.54 & 8.27 \\
\hline & - Seed maintenance & 17 & 56.67 & 3 & 8 & 11.76 & 16.67 & 9.44 \\
\hline \multirow[t]{4}{*}{2} & Garden Plant Cultivation & & & & & & & \\
\hline & $\begin{array}{l}\text { - Preparation of planting } \\
\text { media }\end{array}$ & 25 & 83.33 & 3 & 7 & 10.29 & 21.45 & 17.87 \\
\hline & - selection of plant types & 10 & 33.33 & 4 & 6 & 8.82 & 7.35 & 2.45 \\
\hline & - plant maintenance & 12 & 40.00 & 4 & 6 & 8.82 & 8.82 & 3.53 \\
\hline \multirow[t]{4}{*}{3} & $\begin{array}{l}\text { Organic pesticide } \\
\text { manufacturing } \\
\text { technology }\end{array}$ & & & & & & & \\
\hline & $\begin{array}{l}\text { - Familiar with organic } \\
\text { terms }\end{array}$ & 15 & 50.00 & 5 & 5 & 7.35 & 9.19 & 4.60 \\
\hline & $\begin{array}{l}\text { - Know the components } \\
\text { of the materials used }\end{array}$ & 8 & 26.67 & 6 & 4 & 5.88 & 3.92 & 1.05 \\
\hline & - Know how to make & 5 & 16.67 & 6 & 4 & 5.88 & 2.45 & 0.41 \\
\hline \multirow[t]{3}{*}{4} & $\begin{array}{l}\text { Processing of purple } \\
\text { eggplant }\end{array}$ & & & & & & & \\
\hline & - understand how to make & 25 & 83.33 & 7 & 3 & 4.41 & 9.19 & 7.66 \\
\hline & - can do it & 5 & 16.67 & 8 & 3 & 4.41 & 1.84 & 0.31 \\
\hline \multirow[t]{4}{*}{5} & Processing of vegetables & & & & & & & \\
\hline & - understand how to make & 18 & 60.00 & 9 & 2 & 2.94 & 4.41 & 2.65 \\
\hline & - can do it & 5 & 16.67 & 10 & 1 & 1.47 & 0.61 & 0.10 \\
\hline & Total & & 47.95 & & 68 & & & 88.11 \\
\hline
\end{tabular}

The adoption distribution is a comparison of the number of farmers who apply technological innovations to the Tagrimart demonstration plot to the total members (all group members). So, the number of farmers who apply the technology component is $47.95 \%$ (medium classification). The highest intensity of adoption is the preparation of seed planting media which is understood by most members of the farmer groups. Likewise, with the preparation of planting media and how to make purple eggplant lunkhead which has often been carried out by farmers.

The lowest adoption is in the activity of making processed products, where not all members are able to make eggplant lunkhead or processed vegetables into juice drinks, this needs practice because it will be useful when providing added value to the products produced. However, in general the adoption rate of farmer groups in Bengkel Village, Busungbiu District looks very good, with the calculation value obtained as much as $88.11 \%$. where the classification of the adoption rate is included in the category with a high adoption rate.

In general, the technology implemented in farmer groups is a technology that is easy to implement. This is of interest to members of farmer groups. This is in line with the results of research by Mwangi and Kariuki [13] which state that the determinants of adoption of agricultural technology do not always have the same effect on adoption but vary depending on the type of technology introduced. Information technology that can be learned and easy 
to apply encourages farmers to adoption [14]. That individuals who have the motivation to fulfill their needs will be willing to devote their physical and mental energy to doing work [15].

The process of technology adoption is a sociological and psychological process. However, it is also inseparable from the economic process because it is related to the costs, advantages and benefits of applying technology [16]. Farmers' decisions about whether and how to adopt new technologies are conditioned by dynamic interactions between the characteristics of the technology and various conditions and circumstances [17]. Furthermore, Udimal [18] recommends that the introduction of new technology to farmers should go hand in hand with pilot demonstrations in agricultural areas because with it they will develop confidence and eliminate their doubts regarding the technology. In addition, related to the suitability of the technology developed so that it can be adopted by rural communities is conformity with the socio-cultural conditions of the local community. This is also the concern of Muzari et al. [19] in a review entitled The Impacts of Technology Adoption on Smallholder Agricultural Productivity in Sub-Saharan Africa, stated that to encourage the adoption of new technologies, pro-poor agricultural researchers must look beyond just increasing productivity. They should emphasize certain variables that reduce farmers' vulnerability to loss of income, ill health, natural disasters, and other factors. In addition, an understanding of local cultural practices and preferences is important if smallholders are to benefit from agricultural technologies developed through research.

\subsection{Acceptance of farmer groups in the activity of demplot Tagrinov}

Efforts to grow business in farmer groups have been carried out by the management, namely by using two approaches. The first is sourced from the demonstration plot location and the second is through participation in exhibitions. The results of the demonstration plots are marketed to group members in need. Furthermore, if there is over production, sales are made through community shops around the activity location. Besides being used as a product display, it also serves as a place for marketing results.

The average monthly income from the $200 \mathrm{~m}^{2}$ harvest demonstration plot is $\mathrm{Rp}$. 205,333 ,- and the proceeds from the sale of processed exhibition activities amounted to Rp. 985.000,-/exhibition. So, the overall revenue of farmer groups is Rp. 752.556,-/month. So, activities in the yard area that are not so wide, can be used as a source of income for farmer groups and farmer households. This is in line with the opinion of Hanafi [20] which states that innovations that can be tried on a small scale are usually accepted more quickly. Farmerswith small lands can adopt land -saving technologies such as greenhouse technology, zero grazing as an alternative to increasing agricultural production [21]. Kariyasa and Dewi [22] also found that the area of land ownership had no significant effect on the probability of adoption of the Integrated Crop Management Farmer Field School (PTT-SL). [23] Agricultural development with narrow urban land is believed to be a solution to food problems due to the decline in the number of farmers, urbanization, and limited land. However, the results of this study are not in line with the results of research by Peshin et al. [24] that in order to increase the household income of small farmers, nonagricultural economic employment opportunities must be created, where small-scale agriculture in the subtropical region of Jammu\&Kashmir (J\&K) cannot provide economic prosperity.

In addition to optimizing the yard, accuracy is also needed in the selection of cultivated vegetables. The narrowness of the land cultivated, it is necessary commodities that have high economic value and in accordance with local social conditions to be able to provide additional income in the community. [25] Plants used for cultivation in narrow areas are 
plants that harvest quickly and have shallow roots. Especially in the study location, chili, eggplant and shallots are commodities that provide the highest income from other types of vegetables, especially when entering the rainy season and are proven to increase the income of farmer groups in rural areas. [26] In line with the results of research by Maryono, et al. that intensive commercial vegetable farming provides more income and benefits for all rural communities.

[27] That organizing small farms so that they can take advantage of increasing returns to scale higher in the agricultural value chain, by controlling the marketing and the processing of their crops, would further increase non-farm rural employment as well as farm incomes.[28] Especially in the current state of the Covid pandemic, one effort that can be made to improve food security for the surrounding community during the Covid pandemic is to implement organic vegetable farming on a narrow area.In closing the discussion, it is necessary to follow up on the sustainability of the Tagrinov program. Several efforts need to be made, namely: [29] fostering a harmonious and togetherness relationship between AIAT and village level extension workers, synergizing local government programs with introduced agricultural innovations, so that a sustainable dissemination strategy is realized. Besides that, it fosters a "sense of ownership" of the program so that all have responsibility for its implementation. In addition, at this time, related to the dissemination of agricultural innovations in the era of the industrial revolution 4.0, it is important to make breakthroughs in disseminating agricultural technology innovations, including by designing applications that can be accessed by anyone, anytime with the right, fast, and accurate information [30].

\section{Conclusion}

Agricultural technology that is easy and practical in the Tagrinov program can be very well adopted by farmer groups by utilizing available yard land, including: 1) seed preparation technology, 2) garden plant cultivation technology, 3) organic pesticide manufacturing technology, 4) processing purple eggplant products, and 5) processing of vegetable products. In general, the adoption rate of farmer groups looks very good, with a calculated value of $88.11 \%$, where the classification of the adoption rate is included in the category with a high level of adoption. The implementation of the tagrivov program in farmer groups by utilizing narrow land can increase their income by $\mathrm{Rp} 752,556,-$ /month. Farming activities in the small area of the yard can be used as a source of income for farmer groups and farm households.

Acknowledgements. Thank you to all members of the Wisma Karya farmer group in Bengkel Village, Busungbiu District, Buleleng Regency for their availability and active participation in this research. To all the survey team and employees of the Food Crops Office, Buleleng Regency, Bali Province, in the collaborative activities that have been carried out so far, we also say thank you very much.

\section{References}

1. Arifin, HS. Optimizing the use of yards to support household food security. The paper is presented on the thematic discussion of strengthening the basis of household food security. Dramaga, Bogor. 03 April 2010.

2. Rahayu, ES. Empowerment of Farmer Community in Integrated Yard Program in Sambirejo Village, Ngawen District, Gunungkidul Regency. Thesis. Faculty of Agriculture, Eleven Maret University. Surakarta. 186 p. (2010) 
3. Mardiyanto, A. Yard Landscape Planning with Integrated Agricultural System. Thesis. Department of Landscape Architecture, Faculty of Agriculture, Bogor Agricultural University. 145 p. (2009).

4. Cahyati, Y. Presentation transcript. Agro-Innovation Park and Agro-Innovation Mart (Tagrimart) Balitbangtan. https://slideplayer.info/slide/11830344/ (2016), downloaded November 2020.

5. Dajan, A., Introduction to Statistical Methods, (Second Volume, LP3ES, Jakarta 1996).

6. Hendayana, R., Teaching Materials. Technology Perception and Adoption. Presented in Capacity Building Activities for Socio-Economic Researchers in Socio-Economic Analysis and Agricultural Policy. Bogor 19 October - 1 November 2014. BBP2TP Bogor.

7. R. Fitri and Suryani. Elderly and Urban Agriculture. Respati Scientific Journal. 12(1), 59-65 (2021).

8. Ginting. Field work lecture method (Universitas Brawijaya Malang Indonesia 1991).

9. L. Darmawan, Firmansyah, A., Susanto, T., Journal of Development Communication. 17(1), 55-68 (2019).

10. Yahya, M., Agrica Ekstensia. 10 (2), 1-7 (2016).

11. Putri, RE, Astuti, LTW, \& Yanti, N., Agrica Ekstensia. 10(2) p; 8-18 (2016).

12. M Masuku, Selepe, M. and Ngcobo, N., Journal of Human Ecology. 58(3), 153-161. (2017).

13. Mwangi, M and Kariuki, S., Journal of Economics and Sustainable Development. 6(5) $208-2016$ (2015).

14. Bulu, Y. G, Sari, I. N., Utami, S.K., Agrica (Journal of Agribusiness North Sumatra). 13(1), $10-22$ (2020).

15. Suprayitno AR, Sumardjo, Darwis SG, BG Sugihen, Journal of Forestry Social and Economic Research. 8(3) (2011).

16. Bulu, Y. G. and Utami, S. K., Farmers' Perceptions and Motivations Regarding Conservation Technology for Sloping Agricultural Land in Labangka District, Sumbawa Regency. Proceedings of the National Seminar on Building Modern and Innovative Sustainable Agriculture in Support of AEC. Center for the Assessment and Development of Agricultural Technology. 1066 - 1076 (2017).

17. Loevinsohn,M., Sumberg, J., Diagne, A. Under what circumstances and conditions does adoption of technology result in increased agricultural productivity? Protocols. London: EPPI Centre, Social Science Research Unit, Institute of Education, University of London (2012)

18. T.B. Udimal, Jincai, Z., Mensah, O.S, Caesar, A.E., Journal of Economics and Sustainable Development. 8(8), 137 - 148 (2017).

19. Muzari, W., Gatsi, W., Muvhunzi, S., Journal of Sustainable Development. 5(8), 69 77 (2012).

20. Hanafi A. Socializing new ideas (Surabaya Indonesia: National Business. (1994).

21. Yaron, D., Voet, H., \& Dinar, A., American Journal of Agricultural Economics. 74(2), $361-370$ (1992).

22. Kariyasa, K., \& Dewi, YA, International Journal of Food and Agricultural Economics. 1(2), 29-38 (2013).

23. R. Nurjasmi, Respati Scientific Journal. 12(1), 11-28 (2021).

24. R. Peshin, Sharma, R., Kumar, R., Sharma, LK, Dwivedi, S., Nanda, R., Gupta, V., Risam, KS, Agricultural Economics Research Review. 31(2), 259-269 (2018).

25. Surtinah. Surtinah, Journal of Agribusiness. 20(2), 196-205 (2018)

26. Mariyono, J., Kuntariningsih, A., Dewi, HA, Latifah, E., Daroini, PB, Negoro, AA, Victor Afari-Sefa, VA, Luther,G, Economic Journal of Emerging Markets. 9(2), 115-124 (2017). 
27. M. Paul and Gĩthĩnji, M., The Journal of Peasant Studies. 45(4) (2017).

28. K. Trianti, Febriyanto. D, Abidin, Z., Journal of Community Empowerment Learning. 1(4), $265-273$ (2021).

29. Indraningsih, K. S., Forum Penelitian Agro Ekonomi. 35(2), 107-123 (2018).

30. K Mayasari, Muljono. P, Fatchiya, A., Extension Journal. 16(01), 174-184 (2020). 